\title{
LEADERSHIP STYLES IN FAMIILY BUSINESS : AN PT MANDIRI SUKSES UTAMA CASE STUDY
}

\section{Harry Soegiri ${ }^{1}$, Wanda Gema Prasadio Akbar Hidayat ${ }^{2}$, Suryanto $^{3}$}

\begin{abstract}
This study aims to provide insight into the meaning and perception of leadership in the family business at PT Mandiri Sukses Utrama. More specifically, this research tries to understand the family business culture context and its importance in developing leadership. We share the view that organizational realities are negotiated and built on the awareness of collective participants. This study uses interpretative case studies. Interviews, observations and documentary analysis are used to collect data. Family business leadership is embedded in the culture of the community. A leader-owner is not the creator but only the manager of organizational culture because he is also a product of the culture of society. Owners and their inner circle (family and not family members) can collectively play an important role in producing and reproducing legitimate MCS based on the extended family concept. In this case, cultural controls based on shared family norms are the most dominant and simplify process and outcome controls. However, business pragmatism can go hand in hand with culture in providing space for MCS transformation. The family business studied is still run by the first generation of families, does not have a subsidiary. The sample size of this study is limited. This study encourages family business owners to consider the use of strong cultural controls along with bureaucratic control to create sustainable organizations.
\end{abstract}

Keywords: Leadrship Style, Management Control System 


\section{Introduction}

This interpretive study examines the application of leadership and management control systems in the context of family business at PT Mandiri Sukses Utama implementation of Management control. So far, there have only been three studies in the relevant fields: one study examining leadership and MCS, and two studies examining MCS in family businesses (Abernethy et al., 2010; Ansari et al., 1991; Tsamenyi et al., 2008).

Abernethy et al. (2010) conducted a questionnaire-based study and proposed a model to assess the effect of leadership styles on three elements of system management, namely choice of delegation, planning and control systems and performance measurement systems. This study shows that leadership can significantly predict planning implementation and control systems and performance measurement systems. Their study context is general and does not specifically address family business. Ansari et al. (1991) and Tsamenyi et al. (2008) conducted an in-depth interpretive case study that examined the influence of community culture on management control in Pakistani family businesses and family-owned universities in Indonesia. They revealed that the culture of the community was the center of management control systems in these two family businesses. However, leadership was not explicitly discussed in this study. Given the important role of owner-leaders in the implementation of management control systems, there is a need to add literature on family business' management control in relation to leadership issues.

This study tries to provide further insight into the meaning and perception of leadership and subsequent management control system practices in the family business at PT Mandiri Sukses Utama. Thus, this study examines the context of family business culture and the perspectives of organizational participants (owner-leaders and employees).

The company studied here is a construction consultant.

It was chosen for several reasons. First, many family members 
of the founders participate in daily management activities. This provides a very strong family culture for the company, which is suitable for the purpose of this study. Second, the founder of the company is still active as the Chief Executive Officer (CEO). Third, the company is growing rapidly. This allows us to gain insight into how company development characterizes organizational changes, including the design and implementation of leadership and system management control. Finally, the company strongly supports this research, allowing us to get the data needed.

this paper is organized as follows. review literature on family business, leadership, and system management control. explain the research philosophy and methods used. Empirically describes the company's background, owner-CEO (Mr. HR), characteristics of owner leadership and system management at PT Mandiri Sukses Utama. Theoretical implications and conclusions are discussed at the end of this paper.

\section{Theory}

\section{A. Family Busines Leadership}

Family business has been defined in many ways (Cater III and Justis, 2010; Carlock and Ward, 2010; Dyer, Jr., 2006; Astrachan and Shanker, 2003). Relevant dimensions include the degree of ownership and management by the family and the ability to move from one generation to the next. In this study, "family business" is defined as a company where the family has dominant ownership and control management. The values of the owner family are dominant in the family business because they are transferred to jobs not famil.

Leadership is the process of influencing others to understand and agree on what needs to be done and how to do it, and that is the process of facilitating individual and collective efforts to achieve common goals (Yukl, 2010). This is important because it affects the effectiveness of the organization. Furthermore, Schein (2010) states that entrepreneurial thinking of leaders about what to do and

Vol. 27, No. 2 August 2019

(C) Centre for Indonesian Accounting and Management Research Postgraduate Program, Brawijaya University 
how to do it will create conditions for cultural formation and evolution. Leader values are considered as a source of organizational culture to create internal integration among members of the organization. Leadership is a cultural contingent because the culture of the community has hope regarding leadership roles and characteristics in relation to the ways things should be done in the community (Jogulu, 2010). Therefore, a leader must know what leadership skills and knowledge are valued in the community to develop different leadership competencies in different workplaces

The literature above reflects the profound influence of the structural-functional framework on culture and the study of leadership in organizations. Meek (1988, p. 456) states that the framework tends to narrowly "assume that culture is a unifying force in organizations, that there is a universal homogeneous culture, and that the task of researchers is to find it". Furthermore, it is assumed that leaders are fully able to create and manipulate culture as a variable to unite members to achieve company goals. In contrast, Meek (p. 458) emphasizes that the extent to which norms are internalized and creates an integrated and stable structure.

The literature above reflects the profound influence of the structural-functional framework on culture and the study of leadership in organizations. Meek (1988, p. 456) states that the framework tends to narrowly "assume that culture is a unifying force in organizations, that there is a universal homogeneous culture, and that the task of researchers is to find it". Furthermore, it is assumed that leaders are fully able to create and manipulate culture as a variable to unite members to achieve company goals. In contrast, Meek (p. 458) emphasizes that the extent to which norms are internalized and creates integrated and stable structures is an empirical question rather than something that must be assumed through theory. 
Family business may have its own culture and structure that facilitates interaction between members. Because leadership is also part of total organizational culture, leadership can be understood by referring explicitly to the cultural context of a particular family business and investigating the concrete behavior of its members. The adoption of a framework allows researchers to understand the dynamics of production and the reproduction of family values in the organization, the role of leaders in the process, the role of members, and the intersubjective reality made by all participants regarding power, authority, conflict and change. In other words, much deeper insight into leadership in the context of a family business can be obtained.

\section{B. Management Control System}

Management control and leadership are inseparable. There is no leadership without management control and vice versa. Management control is defined as a system in which social, cultural, political and economic environments are used by management to harmonize employee behavior with organizational goals and to manage internal and external interdependencies (Efferin and Hopper, 2007). This consists of results, processes and cultural controls (Merchant and Van der Stede, 2007; Efferin and Soeherman, 2010). They are not mutually exclusive, but rather overlap and reinforce each other in daily implementation. Result controls determine the expected output of the employee (also known as performance measurement). This type of control provides flexibility, requires delegation of authority and promotes creativity among employees to seek alternative actions to achieve a set target set. Process control focuses on employee means / behavior rather than goals (results) to promote compliance with the desired set of actions. Cultural control promotes a strong and positive cultural organization, allowing organizational members / actors to monitor each other and have self-awareness in doing the best for their organization.

Vol. 27, No. 2 August 2019 
Research on management control systems in less developed countries is an emerging field, but the number of related studies published is still relatively low (Efferin and Hopper, 2007; Tsamenyi et al., 2008; Hoque and Hopper, 1994; Ansari et al., 1991; Wickramasinghe and Hopper, 2005; Uddin and Hopper, 2001). All of these studies use an in-depth case study approach to explore and understand the specific context and meaning of management control systems in the appropriate environment. Although the variation is high and contextual, the results of the study highlight several general characteristics of developed countries in system control management. First, the use of informal controls is more prevalent in developing countries than in developed countries. These controls include ways to communicate expectations / goals, determine roles and expectations of individuals, monitor activities, define job descriptions and design rewards and penalties. Second, community culture significantly characterizes the design and implementation of MCS. Although culture does not operate exclusively, the inclusion of a cultural perspective can explain why a management control system works as it should. Third, local institutions (politics, history, education level and socio-cultural practices) in the business environment of the company, at least, are as important as economic-rational factors in giving legitimacy to the management control system. The acceptance of management control system not only lies in how rational it is but also how well it reflects the world view of the participants. Management control systems, thus, become social processes rather than calculative economic processes to overcome the challenges facing managers

Tsamenyi et al. (2008) conducted a study of system control management in family-owned universities in Indonesia. It was concluded that although some rationaltechnical controls (including budgeting, performance measurement, incentive systems and administrative 
controls) exist, they are subject to control based on culture and social relations. Informal control comes from the personal values of the owner and the culture of the surrounding community, mainly consisting of three Javanese values: bapakisme (paternalism and protection), harmony (collective decision making, unanimous decision and cooperation) and ewuh pakewuh (reluctance among non-supervisors family to punish subordinates who have ties with family). As a result, these values become ideologies with the highest legitimacy possessed by all members of the organization overcoming the management control tools applied in the organization.

\section{Research methods}

To capture a detailed understanding of how management control practices were built and negotiated socially, we adopted the analytical framework of culture and leadership (1988) and the concept of Javanese culture as ethical views. The Meek framework is used to explain the origin and implementation of leadership. Javanese culture is used to examine the cultural values of all organizational participants. Frame ethics is then combined with the emotional views of the participants on how they see the reality of their organization (Efferin and Hopper, 2007). The process is: the emotional view of interpreting this through an ethical frame obtaining confirmation from the participants explaining the similarities / differences. In doing so, we use three methods of data collection: interviews, observation and documentary analysis

His personal background helped identify several key econcepts with original terms that became a big problem in the company and were used consistently by other participants in the next interview. This reveals that there is a strong consensus among the participants regarding important things to focus on in the company. The similarity of ways of thinking between them is interesting, showing that organizational culture is relatively very stable. However, several different concepts and terms are found when interviewing certain marketing agents. This reveals that cultural deviations that produce different

Vol. 27, No. 2 August 2019

(C) Centre for Indonesian Accounting and Management Research Postgraduate Program, Brawijaya University 
behaviors are in the marketing department. In this situation, we use the perception of marketing agents as supporting concepts to understand their culture.

To deal with cultural sensitivity, researchers build personal relationships that are close to the subject. Relationships grow gradually as our friendship and mutual trust become stronger. By doing so, special attention is paid to the company's social norms (sense of humor, behavior, body language, and how to ask questions) to avoid negative impressions in the eyes of all participants (annoying, suspicious, or threatening). To gain trust from the subject, we emphasize that we will not publish sensitive information without their consent. Fortunately, we have permission to publish all relevant information. Close relationships allow researchers to gain access and openness from all organizational participants

\section{Background of PT MSU and the owner}

PT Mandiri Sukses Utama is a company engaged in consulting services in the area of regional fund spatial planning, architecture, structure, mechanical, electrical, plumbing and other engineering fields. Our business arises from understanding and hope to be the best in the world. Reflects good values applied and corporate culture.

- We are very bent on having confidence

- The meaning of honesty in business is the basic thing for the next process. We must deliver data, information, results of analysis and actual realization of work results

- Communication is a way to explain and create mutual understanding, we and partners. Therefore we always deliver services in language that is clear and in line with professional ethics

- We are very aware of the surrounding environment

The goal of the company is to make a qualified and trusted consultant planning, architecture and engineering company that guarantees service user satisfaction, employee 
welfare and profit for shareholders and without neglecting the benefit of the surrounding

All of our services are recommended to have high commitment to meet project needs with their expertise. We have experts from various disciplines to maximize the quality that we will convey. We believe that MSU can meet partner expectations now and later. MSU always strives to maintain the quality of its human resources whose quality must develop in line with the development of the company. By creating a corporate environment that keeps our team learning and developing. Complete the work quickly and the solution becomes a joint commitment.

This company is a professional company, MSU has a way to run the company by making people who have high vision and professionalism to answer the challenges in this industry. In addition to being filled with reliable human resources, MSU is also supported by a well-functioning system.

\section{Personal Background Mr HR}

MrHR is a former head of service in one of the offices in East Java provins with a strong influence of Javanese cultural values. He holds a Bachelor's degree to an economics doctor and has four siblings. His father was very gentle and patient. Mr. HR had learned a lot from him about the meaning of his father's patience and sacrifice

Mr. HR's mother is a strict woman. He often uses rattan sticks to discipline his five sons to follow family rules (eg time management, courtesy, responsibility, etc.). If one of his sons made a mistake, he would punish them all for promoting a sense of solidarity and watching each other between them. However, after the punishment, he will treat his son's wounds gently and explain why he should do it. Mr. HR's childhood experience shaped his character and way of thinking to this day.

\section{Mr. HR's Leadership Style}

Mr. HR believes that his leadership style is the key to managing the company and must be preserved in the future. 
Once, he stated that he wanted to make "more TDs to run the company". His leadership style consists of three characteristics: father's model, concentric circle of trust, and tug of war. They are very influenced by Javanese culture where he and his employees are part of a wider community that practices culture to various levels. As stated by Meek (1988), a leader does not create culture because a leader is a part of culture. Family education and Mr. HR's experience in interacting with various people have instilled certain values reflected in his leadership style.

\section{Theoretical implications and conclusions}

This study has at least three potential limitations that require further research. First, the family business examined here is still run by its founders. The impact of succession on organizational culture, leadership characteristics and MCS cannot be investigated. Further research is needed to explain their dynamics after succession. Second, the company does not have a subsidiary. Some subsidiaries may have their own subcultures which, to some extent, may differ from the head office. It is important to conduct further studies to explore the impact of subcultures on leadership and MCS. Third, Indonesian paternalistic culture is embedded in the family business. Different cultures may differ in influencing leadership and MCS. Further studies comparing family businesses in various countries are very important in gaining a more comprehensive understanding

The family business plays an important role in the economies of less developed countries because their numbers are very dominant. Furthermore, the number of less developed countries far exceeds the number of developed countries. Therefore, the future of business in the era of globalization will 
depend heavily on the transformation of family businesses in less developed countries. We hope that more contextual theories can be produced to help understand and explain the transformation of leadership styles and MCS practices in family businesses.

\section{Daftar Pustaka}

Abernethy, M.A., Bouwens, J. and van Lent, L. (2010), "Leadership and control system design”, Management Accounting Research, Vol. 21 No. 1, pp. 2-16.

Ansari, S.L. and Bell, D.J. (1991), "Symbolism, collectivism and rationality in organisational control", Accounting Auditing and Accountability Journal, Vol. 4 No. 2, pp. 4-27.

Astrachan, J.H. and Shanker, M.C. (2003), "Family businesses' contribution to the US economy: a look", Family Business Review, Vol. 16 No. 3, pp. 211-220.

Beatty, A. (1999), Varieties of Javanese religion: An anthropological account. Cambridge University Press, Cambridge.

Bhimani, A. (1999), "Mapping methodological frontiers in crossnational management control research", Accounting, Organizations and Society, Vol. 24, pp. 413-440.

Carlock, R.S. and dan Ward, J.L. (2010), When Family Businesses are Best: The Parallel Planning Process for Family Harmony and Business Success, Palgrave Macmillan, London.

Cater, III J.J. and Justis, R.T. (2010), "The development and implementation of shared leadership in multi-generational family firms", Management Research Review, Vol. 33 No. 6, pp. 563-585.

Corbetta, G. (1995), "Patterns of development of family businesses in Italy”, Family Business Review, Vol. 8 No. 4, pp. 267-291.

Dyer, Jr., W.G. (2006), "Examining the 'family effect' on firm performance", Family Business Review, Vol. 19 No. 4, pp. 253-273. 
Efferin, S. (2010), "Triangulation in qualitative-interpretive research in accounting: The art of managing limitation", in The Application of Meta Analysis and Triangulation Method Proceedings of National Colloquium and Seminar of M.Sc and Doctoral Programmes, Faculty of Economics and Business, Gadjah Mada University, Indonesia, pp. $1-10$.

Efferin, S. and Hopper, T. (2007), "Management control, culture and ethnicity in a Chinese Indonesian company", Accounting, Organizations and Society, Vol. 32, pp. 223-262.

Efferin, S. and Soeherman, B. (2010), Seni Perang Sun Zi dan Sistem Pengendalian Manajemen: Filosofi dan Aplikasi (Sun Zi's the Art of War and Management Control System: Philosophy and Application), PT. Elex Media Komputindo, Jakarta, Indonesia.

Geertz, C. (1961), The Javanese Family: A Study of Kinship and Socialization, The Free Press of Glencoe, New York, NY.

Geertz, C. (1973), The Interpretation of Culture, Hutchinson, London. Hopper, T. and Powell, A. (1985), "Making sense of research into the organizational and social aspects of management accounting: a review of its underlying assumptions", Journal of Management Studies, Vol. 22 No. 5, pp. 429-465.

Hoque, Z. and Hopper, T. (1994), "Rationality, accounting and politics: a case study of management control in a Bangladeshi jute mill", Management Accounting Research, Vol. 5 No. 5, pp. 5-30.

Jiang, Y. and Peng, M.W. (2011), "Are family ownership and control in large firms good, bad, or irrelevant?", Asia Pacific Journal of Management, Vol. 28 No. 1, pp. 15-39.

Jogulu, U. (2010), “Culturally-linked leadership styles”, Leadership \& Organization Development Journal, Vol. 31 No. 8, pp. 705-719.'

Klein, S.B. (2000), "Family businesses in Germany: significance and structure", Family Business Review, Vol. 8 No. 3, pp. 157-181. 
Koentjaraningrat (1985), Javanese Culture, Oxford University Press, Singapore. Mason, J. (1996), Qualitative Researching, Sage Publications, London.

Meek, V.L. (1988), "Organizational culture: origin and weaknesses", Organization Studies, Vol. 9 No. 4, pp. 453-473.

Merchant, K.A. and van der Stede, W.A. (2007), Management Control Systems: Performance

Measurement, Evaluation and Incentives. Prentice-Hall, London.

Neuman, W.L. (2011), Social Research Methods: Qualitative and Quantitative Approaches, 7th ed.,

Pearson Education Inc., Boston, NY.

Rademakers, M.F.L. (1998), "Market organization in Indonesia: javanese and chinese family business in the jamu industry", Organization Studies Vol. 19 No. 6, pp. 1005-1027.

Schein, E.H. (2010), Organizational Culture and Leadership, 4th ed., John Wiley \& Sons, San Fransisco, CA.

Suryadinata, L., Arifin, E.N. and Ananta, A. (2003), Penduduk Indonesia: Etnis dan Agama dalam Era Perubahan Politik. LP3ES, Jakarta, Indonesia.

Tsamenyi, M., Noormansyah, I. and Uddin, S. (2008), "Management controls in family-owned businesses (FOBs): a case study of an Indonesian family-owned university", Accounting Forum, Vol. 32 No. 1, pp. 62-74.

Uddin, S. and T. Hopper (2001), "A Bangladeshi soap opera: privatisation, accounting and regimes of control in a less developed country", Accounting, Organizations and Society, Vol. 26 Nos 7/8, pp. 643-672.

Wickramasinghe, D. and Hopper, T. (2005), "A cultural political economy of management accounting controls: a case study of a textile mill in a traditional Sinhalese village", Critical Perspectives on Accounting, Vol. 16 No. 4, pp. 473-503.

Vol. 27, No. 2 August 2019

(C) Centre for Indonesian Accounting and Management Research Postgraduate Program, Brawijaya University 
186 Leadership Styles In Family Business. . . . .

Yukl, G. (2010), Leadership in Organizations, 7th ed., Pearson Education, Inc., NJ. 